\title{
Aplikasi THE MODEL Untuk Level Organisasi
}

\author{
Arief Fahmie \\ Fakultas Psikologi dan Ilmu Sosial Budaya, Universitas Islam Indonesia \\ E-mail: a.fahmie@uii.ac.id \\ Nopriadi Hermani \\ Fakultas Teknik, Universitas Gadjah Mada \\ Muthia Nurrakhmi \\ Fakultas Psikologi dan Ilmu Sosial Budaya, Universitas Islam Indonesia
}

\begin{abstract}
An organization needs to determine its development model that is able facilitate it to achieve the goals of development and for improving both the individuals and performances. The MODEL is a personal development design-based on Islamic ideology that combines artificial intelligence theories and Islamic concepts. It consists of four components The Principle (Islam Principle and Sunnatullah Principle), The Vision (True Vision and Big Vision), The Character (Islamic Personality and Efective Character), and The Responsibility (Personal Responsibility and Mabdai Responsibility). This paper aims to describe a theoretical application of The MODEL in organizational context. Applications of it in organizations are related to keys elements that exist in the organization: the people, the work, the formal organization, and the informal organization. The MODEL for organizations is also applied in accordance with organization life cycle. The applications connected with key elements of organization and organization life cycle focus not only on personal development, but also have responsibility to build a world civilization based on Islamic rules (syariah).
\end{abstract}

Key word:The MODEL, development, organization, spiritual-ideological

Suatu organisasi perlu menentukan model pengembangan yang dapat membantu organisasi untuk mewujudkan tujuan pengembangan dan untuk peningkatan kinerja. The MODEL merupakan desain pengembangan diri berbasis ideologi Islam yang menggabungkan konsep kecerdasan buatan dan konsep Islami. The MODEL terdiri dari empat komponen: The Principle (Islam Principle and Sunnatullah Principle), The Vision (True Vision and Big Vision), The Character (Islamic Personality and Efective Character), dan The Responsibility (Personal Responsibility and Mabdai Responsibility).Artikel ini bertujuan memberikan gambaran penerapan The MODEL sebagai sebuah desain pengembangan yang dapat diterapkan pada konteks organisasi. Setiap komponen The MODELdapat diaplikasikan untuk organisasi. Penerapan The MODEL di organisasi akan berkaitan dengan elemen-elemen yang ada pada organisasi yaitu manusia, pekerjaan, organisasi formal, danorganisasi nonformal. The MODEL untuk organisasi juga dapat diterapkan sesuai dengan tahapan hidup kehidupan organisasi. Penerapan-penerapan tersebut berfokus pada membangun peradaban dunia yang berbasis pada syariat Islam.

Kata kunci: The MODEL, pengembangan, organisasi, spiritual-ideologis

Champoux (2011) mendefinisikan organisasi adalah suatu sistem yang terdiri dari dua orang atau lebih, yang terlibat dalam sebuah kerja sama untuk mencapai tujuan. McShane dan Von Glinow (2010) mendefinisikan adalah sekelompok orang yang saling bekerja sama antara satu dengan lainnya untuk mewujudkan tujuan-tujuan yang telah ditetapkan. Sedangkan menurut 
Landy dan Conte (2013), organisasi adalah sekelompok orang yang memiliki kesamaan tujuan dan bersama-sama mengikuti serangkaian prosedur yang telah ditetapkan untuk mengembangkan produk dan jasa.

Organisasi sebagai sebuah sistem memiliki elemen-elemen yang membentuk organisasi tersebut. Hal tersebut dijelaskan oleh Stanford (2005) yang menyatakan bahwa di dalam organisasi terdapat empat elemen utama yang saling terkait dan apabila terjadi perubahan pada sebuah elemen, hal tersebut akan mempengaruhi elemen lainnya. Keempat elemen di dalam organisasi tersebut adalah the work, the people, the formal organization, dan the informal organization.

Pertama, the work atau pekerjaan. Pekerjaan merupakan tugas pokok yang harus diselesaikan oleh organisasi dan bagian-bagian yang terdapat di dalamnya termasuk juga yang berkaitan dengan peran dan konten pekerjaan, desain pekerjaan, jumlah individu yang terlibat dalam sebuah pekerjaan dan tingkat penyelesaian sebuah pekerjaan.

Kedua, the people atau manusia. The people merupakan karakteristik individu dalam sebuah organisasi yang meliputi keterampilan, kemampuan, bakat, talenta, profil demografis, masa kerja, dan masa jabatan.

Ketiga, the formal organization atau organisasi formal. Organisasi formal meliputi struktur yang jelas dan dapat diuraikan, hirarki organisasi, proses alur kerja, sistem dan metode yang secara resmi dibuat agar diikuti oleh setiap individu di organisasi dalam melaksanakan pekerjaannya.

Keempat, the informal organization atau organisasi nonformal. Organisasi nonformal merupakan aturan implisit atau tersirat yang berlaku dan berkembang di dalam organisasi, termasuk di dalamnya berbagai norma, kebiasaan, dan hubungan antar individu di organisasi menjadi budaya atau nilai-nilai umum bagi setiap individu dalam bertindak dan berperilaku di organisasi. Organisasi nonformal juga mencakup nilai-nilai dan kebiasaan yang diterima secara umum oleh individu di organisasi dalam memutuskan dan melakukan sesuatu baik itu di dalam kelompok maupun di luar kelompok, rutinitas sosial dan hubungan sosial yang memperkuat budaya di organisasi tersebut.

Organisasi sebagai sebuah sistem selain memiliki elemen-elemen, sama halnya seperti manusia juga memiliki tahapan atau siklus kehidupan. Tahapan atau siklus kehidupan organisasi sering disebut organization life cycle. Quinn dan Cameron (Van Tonder \& Ehlers, 2011) mendefinisikan organization life cycle atau siklus kehidupan organisasi sebagai tahapan-tahapan perkembangan yang dijalani oleh sebuah organisasi secara berurutan, terjadi secara alami, melibatkan kegiatan-kegiatan dan struktur organisasi sesuai perkembangannya dan kecil adanya kemungkinan untuk bergerak mundur. Sedangkan Hanks dkk (1993) mendefinisikan siklus kehidupan organisasi sebagai konfigurasi unik setiap variabel yang terkait pada kondisi dan struktur sebuah organisasi.

Organization life cycle oleh Ionescu dan Negruşa (2007) secara umum dibagi menjadi tiga fase, yaitu birth atau fase lahir, youth atau fase muda, dan maturity/decline atau fase matang/penurunan.

Pertama, fase birth atau kelahiran. Fase ini tercipta dari dua cara umum yaitu dibentuk dan dijalankan oleh perseorangan atau dapat juga kumpulan beberapa orang yang secara agresif mempromosikan ide, produk atau jasa baru. Kesamaan motif dari keduanya adalah keinginan untuk mendapatkan keuntungan.

Kedua, fase youth atau muda. Organisasi yang pada awalnya dijalankan melalui cara-cara tradisional, dan berfokus pada keuntungan, pada fase ini bergeser pada fokus pertumbuhan. Pertumbuhan organisasi merupakan fokus utama. Dampak yang akan terjadi pada fase ini adalah, pertama, tujuan organisasi menjadi kurang spesifik dan kurang terukur. Kedua, fokus organisasi terletak pada divisi pemasaran, adanya harapan akan peningkatan penjualan terkadang menjadikan pembenaran akan tindakan-tindakan yang dilakukan oleh tim manajemen. 
Ketiga, fase maturity/decline atau masa matang/penurunan (maturity/decline). Pada fase ini, organisasi telah mencapai tahap matang dan mulai menurun. Fokus utamanya pada kemampuan untuk tetap dapat bertahan hidup. Pada fase ini organisasi telah menerapkan teknologi yang kompleks dan canggih, strukturnya birokratis, berorientasi pada kelancaran dan ketahanan finansial. Faktor utama yang mempengaruhi organisasi adalah adanya tekanan yang dipengaruhi oleh persaingan pasar dan adanya tanggung jawab sosial. Fase ini menekankan pada kebersatuan usaha setiap anggota di dalam organisasi. Pada fase ini, organisasi mencoba untuk mempelajari kembali struktur organisasi dan kegiatan operasional dalam rangka untuk membalikkan penurunan yang dialami.

Pembagian mengenai tahapan kehidupan organisasi secara lebih spesifik dijelaskan juga oleh Daft (2010). Daft membagi tahapan kehidupan organisasi menjadi empat tahap, yaitu entrepreneurial stage, collectivity stage, formalization stage, dan elaboration stage.

Entrepreneurial stage. Ketika sebuah organisasi baru terlahir, fokus utamanya terletak pada penciptaan barang atau jasa dan berusaha agar tetap dapat bertahan. Fokus pada tahap ini adalah pada proses produksi barang atau jasa dan strategi pemasarannya atau dapat juga pada proses penciptaan barang atau jasa yang baru. Pada tahap ini organisasi bersifat informal dan non birokratis. Pengendalian didasarkan pada pengawasan pribadi pemiliki organisasi. Krisis yang dihadapi pada tahap ini adalah dibutuhkannya kepemimpinan pada organisasi tesebut.

Collectivity stage. Pada tahap ini organisasi mulai mengembangkan arah dan tujuan yang jelas. Departemen-departemen yang dibutuhkan ditetapkan bersamaan dengan ditetapkannya juga hirarki kewenangan dan perintah, job assignment, dan dilakukannya pembagian tenaga kerja. Pada tahap ini karyawan dikelompokan sesuai dengan misi organisasi. Komunikasi dan kendali sebagian besar masih bersifat non formal walaupun sistem formal mulai tampak di organisasi tersebut. Pada tahap ini organisasi harus menciptakan sebuah mekanisme pengendalian dan pengkoordinasian yang baik disetiap departemen tanpa harus melibatkan pengawasan langsung dari manajer puncak.

Formalization stage. Tahap formalisasi melibatkan penerapan dan penggunaan seperangkat aturan, prosedur, dan sistem kendali. Komunikasi menjadi jarang dilakukan dan umumnya bersifat lebih formal. Tenaga ahli, spesialis SDM, dan staf lainnya mulai ditambahkan jumlahnya. Manajemen puncak mulai beralih pada isu-isu lain seperti strategi dan perencanaan organisasi kedepan dan menyerahkan urusan operasional perusahaan pada manajemen tingkat menengah. Pada tahap ini organisasi mulai membentuk unit-unit desentralisasi untuk meningkatkan koordinasi. Sistem insentif berdasarkan keuntungan mulai diimplementasikan untuk merangsang manajer agar semakin giat mengusahakan yang terbaik bagi organisasi.

Elaboration stage. Pada tahap ini dikembangkan keterampilan untuk mengatasi masalah dan saling bekerja sama antar satu dengan lainnya. Sistem birokrasi telah mencapai batasnya. Kendali sosial dan disiplin diri mengurangi kebutuhan akan penambahan kendali resmi. Pada tahap ini krisis yang dihadapi adalah dibutuhkannya revitalisasi. Setelah organisasi mencapai tahap kematangan, organisasi dimungkinkan mulai memasuki periode penurunan sementara. Kebutuhan akan adanya pembaharuan di organisasi dapat terjadi setiap sepuluh sampai dua puluh tahun sekali.

Berbicara mengenai organisasi yang selalu tumbuh dan berkembang sesuai tahapan kehidupannya, maka diperlukan upaya pengembangan untuk terus meningkatan kualitas organisasi ataupun untuk terus dapat bertahan di era persaingan yang semakin kompetitif. Sehingga organisasi perlu menentukan model pengembangan yang dapat membantu organisasi untuk mewujudkan tujuan pengembangan dan mewujudkan tujuan peningkatan kualitas organisasi tersebut. Saat ini, ada sebuah model pengembangan berbasis spiritual-ideologis yang dikembangkan oleh Hermani (2014), model pengembangan tersebut dikenal dengan istilah The MODEL. 
Konsep awal The MODEL pada mulanya adalah konsep pengembangan untuk diri atau individu, namun karena The MODEL berbicara dari sudut pandang yang luas dan komprehensif, desain pengembangan ini tidak hanya dapat diterapkan untuk diri namun juga dapat diterapkan untuk konteks lain. Tulisan ini bertujuan memberikan gambaran penerapan The MODEL sebagai sebuah desain pengembangan yang dapat diterapkan pada organisasi.

\section{The MODEL}

The MODEL merupakan desain pengembangan yang menggabungkan konsep kecerdasan buatan (artificial intelligence) dan konsep Islami. The MODEL tidak hanya berorientasi pada pengembangan pribadi namun berporos pada kontribusi membentuk tata dunia yang lebih baik dan barokah berdasarkan nila-nilai Islam. Konsep The MODEL adalah memiliki prinsip-prinsip atau nilai-nilai yang benar, berorientasi pada keberhasilan dunia dan akhirat, memiliki karakter yang mengantarkan pada pencapaian visi benar dan visi besar, serta memiliki tanggung jawab pribadi dan berkontribusi pada tata dunia yang lebih baik.

The MODEL terdiri atas empat komponen dan setiap komponen terbagi atas dua bagian, yaitu The Principle (Islam Principle dan Sunnatullah Principle), The Vision (True Vision dan Big Vision), The Character (Islamic Personality dan Efective Character), dan The Responsibility (Personal Responsibility dan Mabdai Responsibility).

The Principle (islam principle dan sunnatullah principle). Prinsip adalah nilai-nilai dan faktor-faktor yang rnengendalikan dan membimbing ke arah pengembangan dan implementasi semua kebijakan dan tindakan (Gaspersz, 2007). Sedangkan prinsip menurut konsep The MODEL adalah pusat hidup untuk membangun pribadi. The Principle dijadikan sebagai standar dalam bertindak. The Principle terdiri atas dua, yaitu islam principle dan sunnatullah principle. Islam principle adalah nilai, ajaran, prinsip-prinsip yang bersumber dari Al Qur'an dan Al Hadist. Jadi islam principle merupakan rujukan untuk menghasilkan cara-cara yang benar sesuai nilai-nilai Islam. Sedangkan sunatullah principle merupakan konsep-konsep yang lahir dari pengamatan terhadap proses dan hukum sebab akibat. Penjelasan mengenai Al Quran dan hadist sebagai prinsip (The Principle) dijelaskan dalam ayat berikut.

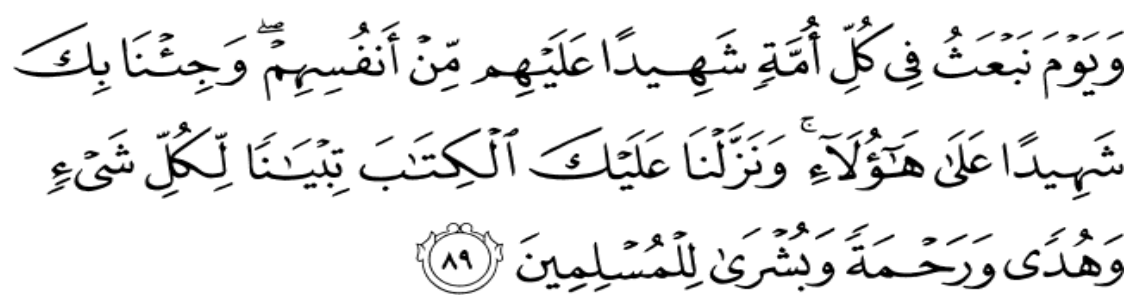

(Dan ingatlah) akan hari (ketika) Kami bangkitkan pada tiap-tiap umat seorang saksi atas mereka dari mereka sendiri dan Kami datangkan kamu (Muhammad) menjadi saksi atas seluruh umat manusia. Dan Kami turunkan kepadamu Al Kitab (Al Quran) untuk menjelaskan segala sesuatu dan petunjuk serta rahmat dan kabar gembira bagi orang-orang yang berserah diri.(QS. An-Naĥl:89)

The Vision (true vision dan big vision). Visi adalah strategi jangka panjang untuk mencapai tujuan dengan menghubungkan masa kini dengan masa depan yang lebih baik (Robbins \& Judge, 2014). Visi menurut The MODEL merupakan visi yang dibuat dengan mempertimbangkan seluruh rentang waktu, dunia dan akhirat, sehingga visi tersebut holistik dan integral. The Vision terdiri atas dua, yaitu true vision dan big vision. True vision adalah visi akhirat. Memiliki visi akhirat berarti terobsesi untuk meraih kesuksesan yang terjadi di hari akhir setelah kehidupan dunia. Sedangkan big vision, yaitu visi dalam kehidupan dunia. Visi 
dunia adalah visi untuk meraih puncak kesuksesan di dunia. Berikut adalah firman Allah SWT yang menyatakan perlunya visi dunia dan visi akhirat.

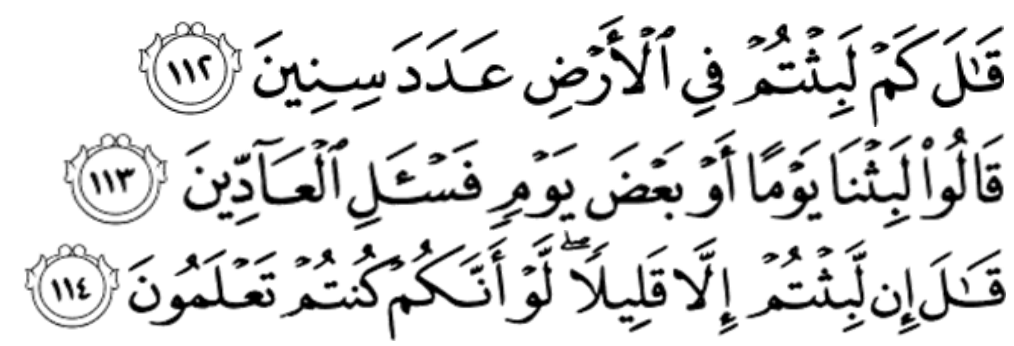

Allah bertanya: "Berapa tahunkah lamanya kamu tinggal di bumi?”. Mereka menjawab: "Kami tinggal (di bumi) sehari atau setengah hari, maka tanyakanlah kepada orang-orang yang menghitung. "Allah berfirman: "Kamu tidak tinggal (di bumi) melainkan sebentar saja, kalau kamu sesungguhnya mengetahui (QS. AlMu'minuun: 112-114).

The Character (islamic personality dan effective character). Karakter adalah cara berpikir, merasa, dan berperilaku. Karakter bisa juga diartikan sebagai kualitas yang dimiliki oleh banyak orang dalam kelompok, negara, dan lain sebagainya (Merriam-Webster Dictionary, 2014). Karakter dalam The MODEL terbagi menjadi dua, yaitu islamic personality atau kepribadian Islam dan efective character atau karakter efektif. Islamic personality adalah pola pikir dan pola sikap yang berdasar pada aqidah dan syariah Islam. Pada penerapan islamic personality, nilainilai Islam dijadikan sebagai standar nilai untuk berpikir dan bertindak. Sedangkan effective character merupakan karakter yang diperlukan untuk berhasil meraih big vision. Penerapan effective character dilakukan melalui mempelajari, memiliki, dan menjalankan ilmu sunatullah. Berikut adalah dua hadist menunjukkan perlunya The Character

Tidaklah beriman salah seorang di antara kamu, sehingga menjadikan saya sebagai (standar) akalnya, yang digunakan untuk berfikir (Muhammad saw).

Jika urusan diserahkan bukan kepada ahlinya, maka tunggulah kehancuran itu (Muhammad saw).

The Responsibility (personal responsibility dan mabdai responsibility). Dalam Islam, responsibility atau tanggung jawab disebut juga amanah. Al-Razi (Islamic Science, 2011) menyebutkan ada tiga macam amanah, yaitu amanah terhadap Allah, amanah terhadap orang lain, dan amanah terhadap diri sendiri. Menurut Konsep The MODEL, The Responsibility merupakan tanggung jawab untuk menjalankan semua peran-peran yang dimiliki. The Responsibility terdiri atas dua, yaitu personal responsibility dan mabdai reponsibility.Personal responsibility menyeimbangkan kesemua peran yang dimiliki untuk bisa seimbang dan selaras, sehingga konflik terkait peran dapat dihindari. Sedangkan mabdai responsibility, yaitu tanggung jawab untuk berkontribusi menata dunia agar menjadi lebih baik, memiliki peran dalam membenahi peradaban (atau lingkungan). Berikut adalah hadist menunjukkan mengenai The Responsibility atau amanah.

Ketahuilah! Masing-masing kamu adalah pemimpin, dan masing-masing kamu akan dimintai pertanggungjawaban terhadap apa yang dipimpin. Seorang kepala negara yang memimpin rakyat adalah pemimpin, dan dia akan dimintai pertanggungjawaban terhadap mereka. Seorang istri juga pemimpin bagi rumah 
tangga serta anak suaminya, dan dia akan dimintai pertanggungjawaban terhadap yang dipimpinnya. Seorang budak juga pemimpin atas harta tuannya, dan dia akan dimintai pertanggungjawaban terhadap apa yang dipimpinnya. Ingatlah! Masing-masing kamu adalah pemimpin dan masing-masing kamu akan dimintai pertanggungjawaban atas apa yang dipimpinnya (Muhammad saw).

\section{Aplikasi The MODEL untuk Organisasi}

Penerapan desain pengembangan The MODEL dapat diterapkan pada konteks organisasi. Setiap komponen The MODEL dapat diaplikasikan untuk organisasi. Penerapan The MODEL di organisasi akan berkaitan dengan elemen-elemen yang ada pada organisasi (the people, the work, the formal organization, the informal organization). Di samping itu aplikasi The MODEL untuk organisasi juga dapat melihat dari tahapan hidup organisasi tersebut (organization life cycle), sehingga aplikasi The MODEL pada setiap organisasi dapat berbeda. Berikut adalah aplikasi The MODEL untuk organisasi secara umum pada masing-masing komponen.

The Principle (Islam Principle dan Sunatullah Principle). Nilai-nilai (value) yang dianut dan diterapkan organisasi yang tercermin pada pemikiran dan tindakan organisasi tersebut. Nilai-nilai yang dianut dan ditanamkan kepada seluruh anggota organisasi berdasarkan pada Al Qur'an dan Hadist. Islamic principle pada organisasi akan tercermin dari budaya, nilai, dan kebiasaan seluruh anggota organisasi, yang bertindak dan berperilaku dengan berpegang pada nilai-nilai Islam. Penerapan Islamic principle pada organisasi juga akan mempengaruhi aturan yang dibuat dan keputusan-keputusan terkait tujuan dan strategi-strategi organisasi, yang mengacu pada benar atau salah dan baik atau buruk berdasarkan nilai-nilai Islam. Nilai-nilai yang dijadikan pedoman juga tidak hanya berfokus untuk keuntungan organisasi semata, tapi seluruh anggota organisasi dan tidak merugikan lingkungan di luar organisasi. Dalam aktivitas sehari-hari, islamic principle dapat juga terlihat dari tindakan dan kebiasaan karyawan dalam bekerja, seperti bekerja dengan keras untuk mencapai target namun tidak menghalalkan caracara yang buruk atau merugikan orang lain, tanggung jawab terhadap tugas, nilai-nilai kejujuran dan lain sebagainya.

Prinsip berikutnya yang menjadi pedoman organisasi adalah sunatullah principle. Prinsip sunatullah akan membawa organisasi mewujudkan tujuan dan visinya. Menurut prinsip sunatullah ada proses-proses yang harus dilalui atau dilakukan untuk memperoleh keberhasilan, sehingga sangat penting untuk memperhatikan setiap proses yang dilakukan organisasi ataupun seluruh komponen organisasi. Memahami input, memperhatikan dan menganalisa proses, serta mengevaluasi output, itulah penggunaan sunatullah principle untuk organisasi.

Sebagai contoh, organisasi yang baru tumbuh/lahir tidak mungkin langsung menjadi besar, organisasi harus melalui tahapn-tahapan kehidupan organisasi tersebut. Saat baru berdiri organisasi melakukan proses-proses untuk dapat bertahan dan membuat organisasi bisa sampai pada fase berkembang, melalui cara-cara mempelajari apa yang dibutuhkan eksternal/pasar. Organisasi mengamati, mempelajari, dan menganalisa prosuk/jasa yang dapat meningkatkan penjualan atau keuntungan perusahaan. Contoh lain penerapan prinsip sunatullah untuk organisasi, misalnya sebelum organisasi melakukan ekspansi terlebih dahulu mempelajari kerugian yang mungkin terjadi dan mempelajari keuntungan yang akan diperoleh, apabila kemungkinan kerugian lebih besar maka perusahaan mengurungkan niatnya untuk melakukan ekspansi yang dapat menimbulkan kerugian besar.

Dua prinsip The MODEL yaitu islam principle dan sunatullah principle saling berkaitan dalam proses pengembangan sebuah organisasi. Organisasi menganut nilai-nilai keislaman sebagai panduan dalam segala tindakan dan keputusan, dan organisasi menjadikan sunatullah principle sebagai pendukung dalam menjalankan aktivitas operasional organisasi. Analogi terkait The Principle seperti ini, organisasi berjalan sesuai jalur yang benar, mengikuti panduan 
dan nilai-nilai yang benar, namun tetap berprinsip untuk tetap mempelajari setiap proses dan sebab akibat yang terjadi selama perjalanan organisasi tersebut.

The Vision (True Vision dan Big Vision). Visi menentukan arah tujuan kemana masa depan organisasi beserta seluruh yang ada di organisasi tersebut. Organisasi sebagai kumpulan manusia yang memiliki siklus hidup, semestinya dalam membuat visi juga mempertimbangkan orang-orang yang ada atau terlibat di dalam organisasi tersebut. Berdasarkan pandangan Islam, manusia hidup tidak hanya di dunia, namun akan ada kehidupan lain setelah dunia, yaitu akhirat. Oleh sebab itu visi organisasi tidak hanya pada visi dunia atau visi dikehidupan saat ini namun juga menentukan visi akhirat.

Dalam istilah The MODEL visi akhirat disebut true vision atau visi benar, sedangkan visi dunia disebut big vision atau visi besar. Big vision adalah visi yang dibuat oleh seluruh organisasi pada umumnya. Tujuan jangka panjang yang ingin diraih organisasi. Namun ada satu visi lagi yang tidak kalah pentingnya dalam menggerakkan dan menumbuhkan organisasi, itulah true vision. Dengan adanya true vision organisasi tidak hanya menjadi sebuah organisasi yang mencari keuntungan semata. Dalam setiap langkah organisasi akan mempertimbangkan nilainilai keakheratan, sehingga kebijakan, keputusan, maupun tindakan yang dilakukan organisasi tidak melanggar pada prinsip-prinsip keislaman yang telah dijadikan panduan (Islam principle).

Organisasi tidak hanya berfokus pada profit oriented, namun memberikan keberkahan bagi organisasi itu sendiri, orang-orang yang menjadi bagian dari organisasi tersebut, dan masyarakat serta lingkungan secara lebih luas lagi. Jadi, organisasi dalam membuat visi tidak hanya berorientasi pada keberhasilan visi dunia seperti menjadi trendsetter IT seluruh Asia, namun menambahkan true vision sebagai perusahaan/organisasi yang memberikan keberkahan bagi seluruh manusia.

The Character (Islamic Personality dan Effective Character). Islam sebagai standar untuk menentukan tindakan. Dalam menentukan solusi terkait permasalahan yang terjadi di dalam organisasi seperti konflik antar karyawan diselesaikan dalam ruang lingkup nilai-nilai Islam. Contohnya, perilaku atasan terhadap bawahan didasarkan pada aqidah dan syariah Islam, seperti tidak berkata kasar kepada bawahan, tidak semena-mena memerintah bawahan, dan lain sebagainya.

Contoh penerapan Islamic personality lainnya di organisasi terkait dalam hal menentukan kebijakan didasarkan pada lima hukum yang ada di Islam, yaitu wajib, sunnah, mubah, makruh, dan haram. Misalnya kebijakan yang wajib dibuat oleh manajemen adalah membayarkan kewajiban karyawan (gaji dan lembur) tepat waktu. Kebijakan yang sunnah dibuat oleh manajemen adalah memberikan bonus-bonus kepada karyawan atas tercapainya target perusahaan. Atau kebijakan yang tidak boleh diberlakukan oleh manajemen seperti melarang karyawan beribadah, melarang karyawan berjilbab, tidak memberikan jatah cuti atau izin kepada karyawan, dan lain sebagainya.

Selain menggunakan lima hukum tersebut, ada contoh lain penerapan Islamic personality, dalam setiap kebijakan atau tindakan yang akan diambil organisasi (pihak manajemen, atasan, atau karyawan) memperhatikan dan mempertimbangkan empat nilai ini secara bersamaan, yaitu nilai materi, nilai kemanusiaan, nilai akhlak, dan nilai spiritual. Organisasi tidak hanya memutuskan sesuatu berdasarkan pada nilai/keuntungan materi, seperti keuntungan penjualan, namun apakah tindakan tersebut akan bermanfaat atau memiliki nilai kemanusiaan, tidak bertentangan dengan kaidah-kaidah, dan tidak menghilangkan nilai spiritual (keakheratan). Misalnya dalam bekerja pihak manajemen menetapkan target penjualan atau keuntungan (nilai materi), namun dari setiap target yang diperoleh organisasi ada kebijakan untuk mendonasikan sedikit keuntungan untuk pendidikan (nilai kemanusiaan), dalam mencapai target karyawan tetap bekerja dengan jujur, tidak melakukan cara-cara yang tidak benar (nilai akhlak), dan tidak meninggalkan nilai spiritual, saat waktunya beribadah (shalat) tidak meninggalkan shalat untuk tetap terus bekerja. 
Karakter berikutnya yang diperlukan untuk mewujudkan visi adalah karakter efektif. Efektif berarti melakukan sesuatu untuk merealisasikan tujuan. Memiliki islam personality namun tidak melakukan cara atau usaha untuk merealisasikannya maka tujuan atau visi organisasi tidak akan terwujud.

Aplikasi karakter efektif di organisasi diilustrasikan sebagai berikut, perusahaan ingin menerapkan sistem baru yang bisa lebih memudahkan kerja karyawan sekaligus lebih mensejahterakan karyawan, namun karyawan tidak diberikan pemahaman dan tidak diajarkan mengenai sistem baru tersebut, dampaknya sistem tersebut tidak bisa diterapkan dan tujuan sistem baru tersebut tidak terealisasi.

Karakter efektif berkaitan dengan prinsip sunatullah. Prinsip sunatullah mempelajari proses-proses dan sebab akibatnya, sedangkan karakter efektif melakukan apa yang telah dipelajari dari ilmu sunatullah. Organisasi menganalisa proses-proses dan sebab akibatnya (sunatullah principle), setelah mengetahuinya dan menetapkan apa yang dibutuhkan, kemudian melakukan tindakan untuk merealisasi output yang telah ditentukan (effective character).

The Responsibility (Personal Responsibility dan Mabdai Responsibility). Syarat pertama menjalankan personal responsibility di organisasi adalah setiap anggota organisasi memahami dengan jelas tanggung jawab dan peran yang diberikan oleh perusahaan/organisasi. Di sinilah fungsi uraian pekerjaan atau prosedur kerja, agar karyawan memahami dengan jelas tanggung jawabnya. Setelah memahami dengan jelas, setiap karyawan harus menjalankan tanggung jawab dan peran tersebut dengan profesional atau dalam Islam dikenal dengan amanah. Karyawan menjalankan setiap tugas dengan sungguh-sungguh, penuh semangat dan motivasi mengerjakan yang terbaik. Namun tidaklah cukup penerapan personal responsibility hanya sampai pada menjalankan peran sesuai amanah. Karyawan diberikan pelatihan atau keahlian/keterampilan yang mendukung pelaksanaan tanggung jawab dan perannya. Karyawan juga dengan sadar mempelajari ilmu sunatullah dan melakukan effective character, tetap berpegang pada islamic principle dan islamic personality, sehingga personal responsibility dapat dilakukan dengan benar dan sesuai.

Selain personal responsibility, The Responsibility yang juga harus dimiliki adalah mabdai responsibility. Organisasi sebagai kumpulan orang-orang, idealnya tidak hanya menjalankan personal responsibility, namun juga menjalankan mabdai responsibility. Organisasi sebagai sekumpulan orang dapat memberikan pengaruh terhadap tata dunia yang lebih baik dengan menjadi teladan bagi organisasi/perusahaan lain melalui prinsip-prinsip, visi, tindakan-tindakan, kebijakan, sistem yang diterapkan organisasi yang menunjukkan nilai-nilai kebaikan dan kebenaran. Organisasi juga dapat membina karyawan dan seluruh yang terlibat dalam organisasi untuk menerapkan nilai-nilai kebaikan dan kebenaran, dan untuk ditularkan atau dibagi kepada lingkungan di luar organisasi. Sehingga peran organisasi dalam masyarakat juga untuk ikut membantu membenahi peradaban menjadi lebih baik.

\section{Kesimpulan}

Berdasarkan penjelasan-penjelasan di atas mengenai The MODEL, sebagai model pengembangan The MODEL dapat memberikan warna baru dalam desain pengembangan di organisasi. Diharapkan dengan penerapan The MODEL untuk organisasi dapat membawa perubahan tidak hanya bagi perkembangan organisasi dan seluruh yang ada di organisasi tersebut namun bagi tata dunia yang lebih baik, sesuai dengan paradigma The MODEL yang tidak hanya berorientasi pada pengembangan semata namun berporos pada kontribusi membentuk tata dunia yang lebih baik dan barokah berdasarkan nila-nilai Islam. 


\section{Daftar Pustaka}

Champoux, J. E. (2011). Organizational behavior: Integrating individuals, groups, and organizations (4th Ed.). New York, NY: Routledge.

Daft, R. L. (2010). Organization theory and design (10th ed.). Mason, OH: South-Western Cengage Learning.

Gaspersz, V. (2007). Lean six sigma for manufacturing and service industries. Jakarta: Gramedia.

Hanks, S. H., Watson, C. J., Jansen, E., \& Chandler G. N. (1993). Tightening the life-cycle construct: A taxonomic study of growth stage configurations in high-technology organizations. Entrepreneurship: Theory and Practice, 18(2), 5-29. Diakses pada tanggal 28 Desember 2014 dari http://www.highbeam.com/doc/1G1-15405303.html

Hermani, N. (2014). The MODEL. Buku pengembangan diri spiritual ideologis untuk meraih sukses pribadi \& peradaban. Yogyakarta: IKKJ Publisher.

Ionescu, G. G. \& Negruşa, A. L. (2007). The study about organizational life cycle models. Review of International Comparative Management, 8(4), 5-17. Diakses pada tanggal 25 Desember 2014 dari www.rmci.ase.ro/Login/no8vol4/Vol8_No4_Article1.pdf

Islamic Science (2011). Konsep amanah dalam Al-Qur'an. Diakses pada tanggal 4 Januari 2015 dari http://sanadthkhusus.blogspot.com/2011/10/konsep-amanah-dalam-al-quran.html

Landy, F. J.\& Conte, J. M. (2013). Work inthe 21st century: An introduction to Industrial and Organizational Psychology (4th Ed.). Hoboken, NJ: John Wiley \& Sons, Inc.

McShane, S. L. \& Von Glinow, M. A. (2010). Organizational behavior: Emerging knowledge and practice for the real world (5th Ed.). New York, NY: McGraw-Hill/Irwin.

Merriam-Webster Dictionary (2014). Character (n.d). Diakses pada tanggal 6 Januari 2015 dari http://www.merriam-webster.com/dictionary/character

Robbins, S. P. \& Judge, T. A. (2014). Essentials of organizational behavior (12th Ed.). Upper Saddle River, NJ: Pearson Education, Inc.

Stanford, N. (2005). Organization design: The collaborative approach. Jordan Hill, Oxford: Elsevier Butterworth-Heinemann.

Van Tonder, E. \& Ehlers, L. (2011). Factors threatening the survival of independent financial advisers in their organisational life cycle: An exploratory study. South African Journal of Economic and Management Sciences, 14(2), 153-169. Diakses pada tanggal 28 Desember 2014 dari http://sajems.org/index.php/sajems/article/viewFile/39/69 